\title{
HE USE OF SOME ORGANIC AND BIO-FERTILIZERS FOR EARLIGRANDE PEACH TREES FERTILIZATION UNDER NORTH SINAI CONDITIONS b: Fruiting and fruit quality
}

\author{
Abdaallah S.El-Kharafen ${ }^{1^{*}}$, H.A. El-Alakmy ${ }^{2}$, R.B. Ahmed ${ }^{1}$, \\ M.M. Sourour ${ }^{2}$ and M.D El-Deeb ${ }^{2}$ \\ 1. Des. Res. Cent., El-Mataria, P. Ocode 11753, Cairo, Egypt. \\ 2. Dept. Plant Prod., Fac. Environ. Agric. Sci., Arish Univ., Egypt.
}

\begin{abstract}
This study aimed to examine the effect of organic sources such as fish scrap, goat manure and olive pomace, type of application (surface and trench) and bio-fertilizer applications (Nitrobein or Rhizobacterein) on flowering, fruit yield and fruit quality of Earligrande peach trees during the two consecutive seasons of 2013/2014 and 2014/2015 at the private Farm at El-Kharafen village in Rafah district, North Sinai Governorate, Egypt. Results indicated that organic fertilization treatments increased number of flowers per shoot, fruit set percentage, total yield, fruit volume and firmness, Vitamin C and total soluble solids (TSS) in both seasons. The fish scrap treatment produced the highest value of each yield measurement, followed by goat manure treatment, then olive pomace treatment compared with nonfertilized trees (control). On the other hand, trench application achieved very significant effect on tree yield $(\mathrm{Kg} /$ tree), fruit weight, fruit volume and firmness compared with surface application in both seasons, But surface application recorded the highest value for each of Vitamin C and total soluble solids (TSS). Also, results showed that Rhizobacterein fertilizer recorded the heights value for each of fruit weight, fruit volume and firmness, Vitamin $\mathrm{C}$ and total soluble solids (TSS). Finally, additive the fish scrap (about $2.77 \mathrm{Kg}$. tree $^{-1}$. Year ${ }^{-1}$ ) with Rhizobacterein fertilizer $(50 \mathrm{~g} /$ tree $)$ in trench application gave the highest fruit properties, fruit yield and improve "Earligrande" peach fruit quality properties in the same experiment conditions.
\end{abstract}

Key words: Peaches (Prunus persica L.), fish scrap, goat manure, trench application, Rhizobacterein fertilizer.

\section{INTRODUCTION}

North Sinai Governorate considered one of the focus points of peach cultivation in a semi-arid region with a total precipitation of about $200 \mathrm{~mm} /$ year, concentrated chiefly in January, February and March (Ahmed and Morsy 2001). In Egypt, the total area declined from 44850 feddan in 2010 to 28355 feddan in 2017. Average production in this region declined from 3.14 ton/feddan in 2010 to 1.64 ton/feddan in 2017 according to Ministry of Agriculture, A.R.E. (2017). Most of the Sinai soils are sandy or calcareous soil which are poor in organic matter and low action exchange and low water holding capacity. Under this conditions fruit trees cultivation needs special treatments to improve the productivity and fruit quality.

Organic fertilization is an important tool in this respect due to its multiple effects as a foundation for clean agriculture, sustainable agriculture, soil condition and a

\footnotetext{
* Corresponding author: Tel.: +201094464995

E-mail address: abdallhkhrfeen@yahoo.com
} 
source of slow release fertilizers (Vogtman and Fricke, 1989, Bahaa, 2007). The application of organic compost increased the yield components and the yield per tree and hectare, especially when $72 \mathrm{~L}$ of compost was applied per tree, without affecting the nutrient contents in the leaves. The addition of organic compost had few effects on the composition of the peach fruit after harvest and after 30 days of storage (Melo et al., 2016). Organic manure alone or in combination was helpful in improving the fruiting and yield of peach cv. Florida Prince (Narayan et al., 2016).

On the same line, Biofertilizers are known to improve fixation of nutrients in the rhizosphere, produce growth stimulants for plants, improve soil stability and provide biological control. Applying biofertilizers has been a good strategy in controlling chemical fertilization, reducing environmental pollution and obtaining safe produts (Hoda, 2012). They also biodegrade substances, recycle nutrients, promote mycorrhiza symbiosis and develop bioremediation processes in soils, contaminated with toxic, xenobiotic and recalcitrant substances (Rivera-Cruz, et al., 2008). Bio-fertilizers are the most importance for plant production and soil as they play an important role in increasing yield and fruit quality (El-Shenawy and Fayed, 2005) on grapevine. Therefore, the main target of this study is to examine the effect of organic sources, type of application and bio-fertilizer applications on flowering, physical and chemical fruit characteristics as well as maximize productivity with high fruit quality of Earligrande peach trees under North Sinai conditions.

\section{MATERIALS AND METHODS}

This study was carried out during the two consecutive seasons of 2013/2014 and 2014/2015 at private Farm at El-Kharafen village in Rafah district, North Sinai Governorate, Egypt. One hundred and twenty eight "Earligrande" peach trees
(Prunus persica L.) about twelve-year-old grown in sandy soil and budded on "Bitter Almond" (Prunus amygdalus L.) were chosen according to their similarity in growth, vigor, productivity and uniform as possible and devoted for achieving this experiments, the annual pruning is a critical management practice for trees similarity $(200-250$ units of fruiting shoots per tree). The trees were planted at $5 \times 5 \mathrm{~m}$ apart and all tested trees received regularly the annual horticultural practices except for mineral fertilization while the untreated trees including the control was fertilized with ammonium sulfate, super phosphate and potassium sulfate at the rate of 200, 75 and $150 \mathrm{~kg}$ per feddan, respectively and depended only on the rainfall which amounted to about $204.71 \mathrm{~mm}$.year ${ }^{-1}$ during the rainfall season from October up to late April.

\section{Treatments and Experimental Design}

\section{Organic Fertilizer Source}

According to the recommendation of Water and Soils Research Institute Ministry of Agriculture, Egypt. The actual nitrogen $\left(\mathrm{g} \mathrm{tree}^{-1}\right.$. Year $\left.{ }^{-}\right)$required to peach tree older than 6 years is $500 \mathrm{~g}$. tree $^{-1}$. Year $^{-1}$ (Table 1).

There upon half of the required nitrogen $\left(250 \mathrm{~g} \mathrm{~N}\right.$. tree ${ }^{-1}$. Year $\left.{ }^{-1}\right)$ was suggested to be satisfied through one of the organic fertilizer sources according to its content of nitrogen as follows:

- Fish scrap $(9.0 \% \mathrm{~N})$ about $2.77 \mathrm{Kg}$. tree ${ }^{-1}$. Year $^{-1}$.

- Goat manure $(1.25 \% \mathrm{~N})$ about $20.0 \mathrm{Kg}$. tree $^{-1}$. Year ${ }^{-1}$.

- Olive pomace $(2.5 \% \mathrm{~N})$ about $10.0 \mathrm{Kg}$. tree $^{-1}$. Year ${ }^{-1}$.

\section{Methods of Organic Fertilizer Application}

Two methods of organic fertilizers were selected as follows:

\section{Surface Application}

On December of each season, the three organic fertilizers were applied superficially and digged in the soil during deep hand hoeing practice (about $5 \mathrm{~cm}$ depth) according to El-Deeb (2003). 
SINAI Journal of Applied Sciences (ISSN: 2314-6079) Vol. (7) Is. (2), Aug. 2018

Table 1. Chemical analysis of tested organic fertilizer materials.

\begin{tabular}{cccccc}
\hline Material & $\begin{array}{c}\text { Total } \mathbf{N} \\
(\%)\end{array}$ & $\begin{array}{c}\text { Total } \mathbf{P}_{2} \mathbf{O}_{5} \\
(\%)\end{array}$ & $\begin{array}{c}\text { Total } \mathbf{K}_{2} \mathbf{O} \\
(\%)\end{array}$ & $\begin{array}{c}\text { Total CaO } \\
(\%)\end{array}$ & $\begin{array}{c}\text { Total MgO } \\
(\%)\end{array}$ \\
\hline Fish scrap & 9.0 & $\begin{array}{c}\text { Animal byproducts } \\
7.1\end{array}$ & - & 8.5 & 0.5 \\
Goat manure & 1.25 & $\begin{array}{c}\text { Excreta } \\
\text { Planet residues } \\
\text { Olive pomace }\end{array}$ & 3 & 2 & 0.1 \\
\hline
\end{tabular}

\section{Trench Application (Subsurface) Application}

Two trenches $(100 \mathrm{~cm}$ length $\mathrm{x} 30 \mathrm{~cm}$ width $\mathrm{x} 25 \mathrm{~cm}$ depth) were digged in December of each season on both sides of tree at $1 \mathrm{~m}$ apart from the tree trunk, then the estimated amount of each organic fertilizer was divided equally and applied in the two trenches and covered with soil (ElDeeb, 2003).

\section{Biofertilizers applications ( $\mathbf{N}$-fixing bacteria)}

The remaining N-requirement for each tree was assumed to be partially satisfied through using N-fixing fertilizers. Rhizobacterein fertilizer is a mixture of nitrogen fixing bacteria (Azotobacter chroococcum and Azospirillum brasilense) while Nitrobein fertilizer containing Azospirillum spp and Azotobacter chroococcum. Such products are produced by the General Organization for Agric. Equalization Fund, Ministry of Agric., Egypt. On late October of each season, the biofertilizers $(50 \mathrm{~g}$ from Nitrobein or Rhizobacterein per tree) were applied in trenches $(40 \mathrm{~cm}$ length $\mathrm{x} 20 \mathrm{~cm}$ width $\mathrm{x} 5$ $\mathrm{cm}$ depth) at $1 \mathrm{~m}$ apart from the tree trunk.

\section{Measurements}

The specific effect of organic fertilizers, method of organic fertilizer application and Biofertilizers as well as their interaction on flowering, fruiting and fruit quality were evaluated through the following measurements:

\section{Number of flowers per shoots and fruit set}

Thirty (one - year - old) shoots were chosen at random and labeled on each tree for each season during full bloom (late
February) to count the total initial number of flowers per shoot, number of fruitlets and fruits were recorded at monthly intervals up to harvest the percentage of $X$, fruits set was calculated according to Ferguson et al., (1994) as follows:

Fruit set $=\frac{\text { No, of developing fruitlets }}{\text { Total initial no of flowers at full bloom }} \times 100$ (\%)

Fruit retention was calculated on the basis of initial number of fruit set and total number of fruitlets drop of each season.

\section{Fruit yield (kg.tree ${ }^{-1}$ )}

At harvest time, (mid-may) the yield was estimated on the basis of number and weight of fruits per peach tree $\left(\mathrm{Kg}\right.$. tree $\left.^{-1}\right)$ as outlined in AOAC (1990). The average yield per feddan was also calculated according to Westwood and Roberts (1970). Fruits per tree were harvested and kept at a normal temperature while transported to the laboratory of the Faculty of Agricultural \& Environmental Sciences at El-Arish, Egypt.

As for the fruit quality, a representative sample was taken from each treated tree about (50 fruits) and subjected to some physical and chemical analyses (AOAC, 1990).

\section{Fruit quality}

\section{Fruit Weight, Fruit Dimensions and} Fruit Firmness

The selected twenty fruits from each tree under study were weighted and the average weight of fruit (g) was determined. The average fruit length (L) and width (W) were measured by using vernier caliper and the 
average was calculated. The fruit shape indexes $(\mathrm{L} / \mathrm{W})$ was calculated. Fruit firmness was measured using 10-15 fruit samples per tree. A hand help pressure tester was used to measure fruit firmness.

\section{Total Soluble Solids And Juice Acidity}

Total soluble solids was measured using 10-15 fruit samples per tree. A hand refractometer was used to determine the total soluble solid percentages. The acidity of fruit juice determined as malic acid by simple direct titration with $0.1 \mathrm{M}$ sodium hydroxide, using phenolphthalein (ph.th) as an indicator according to the methods of AOAC (1990).

- Weight $10 \mathrm{~g}$ of sample in conical flask and add $50 \mathrm{ml}$ distilled water.

- Titrate using $0.1 \mathrm{M} \quad \mathrm{NaOH}$ and phenolphthalein (ph.th) as indicator.

- Calculate the total acidity of fruit juice.

Malle acid $=0.1 \times$ vol. of $\mathrm{NaOH}(\mathrm{ml}) \times 10^{-3} \times 192.43 / 3$

- L-ascorbic acid content (V.C) was determined as mg.100 ml-1 juice according to Bekele and Geleta (2015).

\section{Statistical Analysis}

The results were arranged in a randomized complete block design (three factors split split plots design), while in the third stage results were arranged in a randomized complete block design (for factors strip plots) using MSTATC computer program (Russell, 1986) with four replicates and each replicate was represented by two trees. Duncan's multiple range test was used for comparison between means. Different alphabetical letters in the column are significantly differed at (0.05) level of significance (Duncan, 1955).

\section{RESULTS}

\section{Number of Flowers Per Shoot}

Results in Table 2 reveale that the organic fertilization treatments increased number of flowers per shoot in both seasons. The non-organic fertilized trees (control) recorded the least number of flowers per shoot. While the fish scrap treatment caused a highest significant value in this respect, followed by fertilized trees by goat manure in first season, but olive pomace recorded the highest significant value in the second season. At the end of flowering, all of organic fertilization increased total number of flowers per shoot in both seasons. These results are in the same line of Narayan et al. (2016) who found that organic manure alone or in combination was helpful in improving the flowering of peach cv. Florida Prince. Also, results of Table 2 show that differences between surface and trench application treatments were insignificant number of flowers per shoot at different times during both seasons.

Concerning the specific effect of biofertilizers $\mathrm{N}$-fixing bacteria practices. Table 2 indicates that the insignificant differences between Rhizobacterein and Nitrobein bacteria in both seasons. These results are in the same line with El-Gioushy and Baiea (2015) on "Canino" apricot trees (Prunus armeniaca, L). Respecting the interaction effect between organic fertilizer sources, organic fertilizer application methods and biofertilizers $\mathrm{N}$-fixing bacteria under different methods of application treatments. The results in Table 3 show that the highest number of flowers per shoot were noticed fish scrap or goat manure with Rhizobacterein bacteria under surface application method in first season. But, olive pomace under surface application methods with Rhizobacterein or Nitrobein bacteria achieved high values in this concern in second season. In the meantime the least values were given by non-organic fertilized trees (control) in both seasons.

\section{Fruit Set Percentage}

Results in Table 2 indicate that the organic fertilization treatments increased fruit set percentage in both seasons. The fish 
SINAI Journal of Applied Sciences (ISSN: 2314-6079) Vol. (7) Is. (2), Aug. 2018

Table 2. Specific effect of organic fertilizer source, fertilizer application method and biofertilizers $\mathrm{N}$-fixing bacteria on number of flowers per shoot at different times, fruit set and fruit yield per tree of "Earligrande" peach trees during 2014 and 2015 seasons.

\begin{tabular}{|c|c|c|c|c|c|c|c|c|}
\hline \multirow[t]{2}{*}{ Treatment } & \multicolumn{2}{|c|}{$\begin{array}{c}\text { Number of } \\
\text { flowers/shoot } \\
\text { (beginning of blooming) }\end{array}$} & \multicolumn{2}{|c|}{$\begin{array}{c}\text { Number of } \\
\text { flowers/shoot (End of } \\
\text { blooming) }\end{array}$} & \multicolumn{2}{|c|}{$\begin{array}{c}\text { Fruit set } \\
(\%)\end{array}$} & \multicolumn{2}{|c|}{$\begin{array}{l}\text { Fruit yield } \\
\left(\text { kg.tree }^{-1}\right)\end{array}$} \\
\hline & 2013/2014 & $2014 / 2015$ & 2013/2014 & $2014 / 2015$ & 2013/2014 & $2014 / 2015$ & 2013/2014 & $2014 / 2015$ \\
\hline \multicolumn{9}{|c|}{ Specific effect of organic fertilizer source (OF) } \\
\hline Fish scrap & $7.58 \mathrm{a}$ & $8.16 \mathrm{ab}$ & $17.25 \mathrm{a}$ & $15.00 \mathrm{ab}$ & $28.00 \mathrm{a}$ & $32.00 \mathrm{a}$ & $55.08 \mathrm{a}$ & $62.08 \mathrm{a}$ \\
\hline Goat manure & $7.58 \mathrm{a}$ & $8.91 \mathrm{ab}$ & $16.91 \mathrm{a}$ & $15.83 \mathrm{a}$ & $27.16 \mathrm{a}$ & $32.08 \mathrm{a}$ & $47.50 \mathrm{~b}$ & $51.00 \mathrm{~b}$ \\
\hline Olive pomace & $5.50 \mathrm{~b}$ & $9.50 \mathrm{a}$ & $15.91 \mathrm{a}$ & $15.33 \mathrm{ab}$ & $24.41 \mathrm{~b}$ & $29.08 \mathrm{~b}$ & $35.83 \mathrm{c}$ & $39.08 \mathrm{c}$ \\
\hline Control & $4.50 \mathrm{c}$ & $4.60 \mathrm{~b}$ & $13.00 \mathrm{~b}$ & $13.00 \mathrm{~b}$ & $23.00 \mathrm{~b}$ & $22.00 \mathrm{c}$ & $33.00 \mathrm{~d}$ & $29.33 \mathrm{~d}$ \\
\hline \multicolumn{9}{|c|}{ Specific effect of methods of organic fertilizer application (MA) } \\
\hline $\begin{array}{l}\text { Surface } \\
\text { application }\end{array}$ & $4.75 \mathrm{a}$ & $6.83 \mathrm{a}$ & $15.95 \mathrm{a}$ & $14.83 \mathrm{a}$ & $25.37 \mathrm{~b}$ & $28.62 \mathrm{a}$ & $42.04 \mathrm{~b}$ & $44.25 \mathrm{~b}$ \\
\hline $\begin{array}{l}\text { Trench } \\
\text { application }\end{array}$ & $4.58 \mathrm{a}$ & $7.45 \mathrm{a}$ & $15.58 \mathrm{a}$ & $14.75 \mathrm{a}$ & $26.91 \mathrm{a}$ & $28.95 \mathrm{a}$ & $43.66 \mathrm{a}$ & $46.50 \mathrm{a}$ \\
\hline \multicolumn{9}{|c|}{ Specific effect of Biofertilizers N-fixing bacteria (BF) } \\
\hline Rhizobacterein & $5.58 \mathrm{a}$ & $7.50 \mathrm{a}$ & $15.70 \mathrm{a}$ & $14.62 \mathrm{a}$ & $26.50 \mathrm{a}$ & $29.33 \mathrm{a}$ & $44.45 \mathrm{a}$ & $47.12 \mathrm{a}$ \\
\hline Nitrobein & $4.75 \mathrm{~b}$ & $6.79 \mathrm{~b}$ & $15.83 \mathrm{a}$ & $14.95 \mathrm{a}$ & $25.79 \mathrm{a}$ & $28.25 \mathrm{a}$ & $41.25 \mathrm{~b}$ & $43.62 \mathrm{~b}$ \\
\hline
\end{tabular}

Mean values of treatments were differentiated by using Least Significant Range (Duncan's multiple range test) at 5\% probability

Table 3. The interaction effect between organic fertilizer source, fertilizer application method and biofertilizers $\mathrm{N}$-fixing bacteria on number of flowers per shoot at different times, fruit set and fruit yield per tree of "Earligrande" peach trees during 2014 and 2015 seasons.

\begin{tabular}{|c|c|c|c|c|c|c|c|c|c|c|}
\hline \multicolumn{3}{|c|}{ Treatment } & \multicolumn{2}{|c|}{$\begin{array}{c}\text { Number of } \\
\text { flowers/shoot } \\
\text { (beginning of } \\
\text { blooming) } \\
\end{array}$} & \multicolumn{2}{|c|}{$\begin{array}{c}\text { Number of } \\
\text { flowers/shoot } \\
\text { (End of blooming) }\end{array}$} & \multicolumn{2}{|c|}{$\begin{array}{c}\text { Fruit set } \\
\text { (\%) }\end{array}$} & \multicolumn{2}{|c|}{$\begin{array}{l}\text { Fruit yield } \\
\left(\text { kg.tree }^{-1}\right)\end{array}$} \\
\hline OF & MA & BF & 2013/14 & 2014/15 & 2013/14 & 2014/15 & 2013/14 & $2014 / 15$ & 2013/14 & $2014 / 15$ \\
\hline \multirow{2}{*}{$\begin{array}{l}\text { Fish } \\
\text { scrap }\end{array}$} & Surface & $\begin{array}{l}\text { Rhizobacterein } \\
\text { Nitrobein }\end{array}$ & $\begin{array}{l}8.00 \mathrm{a} \\
6.33 \mathrm{ab}\end{array}$ & $\begin{array}{l}3.33 \mathrm{c} \\
4.33 \mathrm{bc}\end{array}$ & $\begin{array}{l}17.66 \mathrm{a} \\
17.33 \mathrm{a}\end{array}$ & $\begin{array}{l}15.33 \mathrm{ab} \\
15.00 \mathrm{ab}\end{array}$ & $\begin{array}{l}26.00 \text { c-f } \\
28.33 \text { abc }\end{array}$ & $\begin{array}{l}33.33 \mathrm{ab} \\
31.66 \mathrm{bc}\end{array}$ & $\begin{array}{l}57.00 \mathrm{a} \\
55.00 \mathrm{~b}\end{array}$ & $\begin{array}{l}63.33 \mathrm{a} \\
59.00 \mathrm{c}\end{array}$ \\
\hline & Trench & $\begin{array}{l}\text { Rhizobacterein } \\
\text { Nitrobein }\end{array}$ & $\begin{array}{l}8.33 \mathrm{a} \\
7.66 \mathrm{a} \\
\end{array}$ & $\begin{array}{l}12.66 \mathrm{a} \\
4.33 \mathrm{bc} \\
\end{array}$ & $\begin{array}{l}16.33 \mathrm{ab} \\
17.66 \mathrm{a} \\
\end{array}$ & $\begin{array}{l}14.33 \text { ab } \\
15.33 \text { ab } \\
\end{array}$ & $\begin{array}{l}27.66 \mathrm{a}-\mathrm{d} \\
30.00 \mathrm{ab} \\
\end{array}$ & $\begin{array}{l}31.0 \text { bcd } \\
32.00 \text { bc } \\
\end{array}$ & $\begin{array}{l}55.00 \mathrm{~b} \\
53.33 \mathrm{c} \\
\end{array}$ & $\begin{array}{l}64.00 \mathrm{a} \\
62.00 \mathrm{~b} \\
\end{array}$ \\
\hline $\begin{array}{l}\text { Goat } \\
\text { manure }\end{array}$ & Surface & $\begin{array}{l}\text { Rhizobacterein } \\
\text { Nitrobein } \\
\text { Rhizobacterein } \\
\text { Nitrobein }\end{array}$ & $\begin{array}{l}8.33 \mathrm{a} \\
8.33 \mathrm{a} \\
8.33 \mathrm{a} \\
6.33 \mathrm{ab}\end{array}$ & $\begin{array}{l}8.00 \text { abc } \\
8.66 \text { abc } \\
8.33 \text { abc } \\
10.66 \mathrm{abc}\end{array}$ & $\begin{array}{l}16.00 \mathrm{ab} \\
18.66 \mathrm{a} \\
17.00 \mathrm{a} \\
16.00 \mathrm{ab}\end{array}$ & $\begin{array}{l}15.00 \mathrm{ab} \\
16.33 \mathrm{a} \\
15.66 \mathrm{ab} \\
16.33 \mathrm{a}\end{array}$ & $\begin{array}{l}26.33 \text { b-f } \\
24.33 \text { def } \\
31.00 \text { a } \\
27.00 \text { b-e }\end{array}$ & $\begin{array}{l}31.0 \text { bed } \\
31.66 \text { be } \\
34.66 \text { a } \\
31.0 \text { bed }\end{array}$ & $\begin{array}{l}49.33 \mathrm{~d} \\
40.66 \mathrm{f} \\
53.33 \mathrm{c} \\
47.00 \mathrm{e}\end{array}$ & $\begin{array}{l}52.00 \mathrm{e} \\
45.00 \mathrm{~g} \\
57.00 \mathrm{~d} \\
50.00 \mathrm{f}\end{array}$ \\
\hline $\begin{array}{l}\text { Olive } \\
\text { pomace }\end{array}$ & Surface & $\begin{array}{l}\text { Rhizobacterein } \\
\text { Nitrobein } \\
\text { Rhizobacterein } \\
\text { Nitrobein } \\
\end{array}$ & $\begin{array}{l}5.00 \mathrm{~b} \\
5.00 \mathrm{~b} \\
5.66 \mathrm{~b} \\
4.33 \mathrm{c} \\
\end{array}$ & $\begin{array}{l}15.33 \mathrm{a} \\
15.00 \mathrm{a} \\
12.33 \mathrm{ab} \\
7.33 \mathrm{abc} \\
\end{array}$ & $\begin{array}{l}16.33 \mathrm{ab} \\
15.66 \mathrm{ab} \\
16.33 \mathrm{ab} \\
15.33 \mathrm{ab} \\
\end{array}$ & $\begin{array}{l}15.66 \mathrm{ab} \\
15.33 \mathrm{ab} \\
15.00 \mathrm{ab} \\
15.33 \mathrm{ab} \\
\end{array}$ & $\begin{array}{l}25.00 \mathrm{c}-\mathrm{f} \\
23.00 \mathrm{f} \\
26.00 \mathrm{c}-\mathrm{f} \\
23.66 \mathrm{ef} \\
\end{array}$ & $\begin{array}{l}30.33 \mathrm{~cd} \\
27.00 \mathrm{e} \\
30.33 \mathrm{~cd} \\
28.66 \mathrm{de} \\
\end{array}$ & $\begin{array}{l}35.33 \mathrm{~g} \\
33.00 \mathrm{~h} \\
40.00 \mathrm{f} \\
35.00 \mathrm{~g} \\
\end{array}$ & $\begin{array}{l}40.00 \mathrm{i} \\
36.00 \mathrm{k} \\
42.00 \mathrm{~h} \\
38.33 \mathrm{j} \\
\end{array}$ \\
\hline & Contro & & $4.50 \mathrm{c}$ & $4.00 \mathrm{c}$ & $13.00 \mathrm{~b}$ & $13.00 \mathrm{~b}$ & $23.00 \mathrm{f}$ & $22.00 \mathrm{f}$ & $33.00 \mathrm{~h}$ & 29.33 I \\
\hline
\end{tabular}

Mean values of treatments were differentiated by using Least Significant Range (Duncan's multiple range test) at 5\% probability 
scrap and goat manure treatments caused the highest significant value in this respect, followed by fertilized trees by olive pomace in both seasons. On the contrary, the nonorganic fertilized trees (control) recorded the least number of fruit set percentage in both seasons. These results are in the same line of Narayan et al., (2016) on peach cv. Florida Prince.

Concerning the specific effect of methods of organic fertilizer application results of Table 2 show that trench application method achieved high value on fruit set percentage during first season. But, no significant differences between Surface and trench application treatments during second season. As for the specific effect of biofertilizers $\mathrm{N}$-fixing bacteria practices on fruit set percentage. Table 2 revealed no significant differences between Rhizobacterein and Nitrobein bacteria in fruit set percentage during both seasons. This result are in the same line with El-Gioushy and Baiea (2015) on "Canino" apricot trees (Prunus armeniaca).

Respecting the interaction effect between organic fertilizer sources, organic fertilizer application methods and biofertilizers $\mathrm{N}$ fixing bacteria under different methods of application treatments, results in Table 3 show that the highest number of fruit set percentage were noticed with goat manure by due to Rhizobacterein bacteria under trench application method in both seasons. While, least values were given by Nonorganic fertilized trees (control) in both seasons. The other interactions revealed inbetween effect.

\section{Fruit Yield (Kg. tree ${ }^{-1}$ )}

Results given of Table 2 show that the fruit yield was increased linearly by adding the organic fertilization. The fertilized trees with fish scrap was the best treatment and recorded the highest values $(55.08 \& 62.08$ kg.tree $\left.{ }^{-1}\right)$, followed by goat manure treatment $\left(47.50 \& 51.00 \mathrm{~kg} \cdot\right.$ tree $\left.^{-1}\right)$ in both seasons. On the contrary, non-organic fertilized trees (control) had the least values $\left(33.00 \& 29.33\right.$ kg.tree $\left.{ }^{-1}\right)$ respectively in both seasons. Thus, the increment percentage of yield/ tree due to use fish scrap over non-organic fertilizer attained $66.90 \& 111.66 \%$ during both seasons, respectively. These results go in line with those reported by Kassem and El-Seginy (2002), and Narayan et al., (2016) they reported that organic manure had a significant response on fruit yield.

As for the specific effect of methods of organic fertilizer application on fruit yield data of Table 2 clear that trench application treatment achieved a highest significant increase in fruit yield compared to surface application method in both seasons. Concerning the specific effect of biofertilizers $\mathrm{N}$-fixing bacteria practices, data of Table (2) reveal the Rhizobacterein caused high significant effect in fruit yield $(\mathrm{Kg})$ in both seasons. While, Nitrobein treatment resulted in a remarkable decrease in this respect. These results are in agreement with those reported by ElShenawy and Fayed (2005) they found that bio-fertilizers significantly increased yield.

Regarding the response of fruit yield to the interaction effect between organic fertilizer source, organic fertilizer application methods and biofertilizers $\mathrm{N}$-fixing bacteria practices, data of Table 3 reveal that the fish scrap with Rhizobacterein and adding surface of fertilization caused the highest significant increase in fruit yield in first season. While, fish scrap with Rhizobacterein using both methods of adding fertilization treatments recorded the highest value of total yield in second season. Non-organic fertilized trees (control) treatment had the least values in this concern. On the other hand, other interactions induced intermediate values of fruit yield between the previously mentioned categories. These results are in 
agreement with those reported by El-Deeb (2003), who concluded that the application of fish scrap in trenches and enriching with Rhizobacterein gave the highest values of yield per tree.

\section{Fruit weight (g)}

Table 4 reveals that in both study seasons, fruit weight was increased linearly with adding organic manure fertilization. The fish scrap, goat manure and olive pomace fertilizers were similar and gave the highest values in this concern. On the other hand, the non-organic fertilized trees (control) were the most depressive effect in first season but, there were no significant differences between all treatments in second season. This pattern is similar to that reported by El-sayed $\boldsymbol{e t}$ al. (2010) who showed that, fruit quality fruit weight, diameter were, generally, improved under all organic treatments as compared with control on pomegranate trees.

Respecting the specific effect of methods of organic fertilizer application on fruit yield, data of Table 4 illustrate that no significant differences were observed between surface and trench applications in first season. While, the trench application treatment achieved high significant increase in fruit weight compared to surface application method in second season. As for the specific effect of biofertilizers $\mathrm{N}$-fixing bacteria practices, data in the same Table show that Rhizobacterein caused a high significant increase in fruit weight $(\mathrm{g})$. While, Nitrobein gave the least values in this respect during both seasons. Similar results were obtained by Mansour (1998) who found that bio-fertilization had a positive effect on fruit weight of Apple trees. Regarding the interaction effect between organic fertilizer source, organic fertilizer application methods and biofertilizers $\mathrm{N}$-fixing bacteria treatments, data of Table (5) show that fertilization treatments by fish scrap using trench method $\times$ Nitrobein treatment was significantly interactive for fruit weight and gave the highest values in this respect in the both seasons. While, Non-organic fertilized trees (control) treatment had the least values in this regared.The other interactions reveal in between effect.

\section{Pulp/ Stone Ratio}

Table 4 indicates that, pulp/ stone ratio was increased with different source of organic manure fertilization in both seasons. The fish scrap fertilizer achieved the highest values of pulp/ stone ratio, followed by olive pomace treatment in both study seasons. On the other hand, the nonorganic fertilized trees (control) was the most depressive effect in both seasons.

As for the specific effect of methods of organic fertilizer application on fruit yield, data of Table 4 notice that no significant differences between surface and trench applications were found in first season. While, the surface application treatment achieved a highest significant increase in pulp/stone ratio compared to trench application method in second season. Regarding the specific effect of biofertilizers $\mathrm{N}$-fixing bacteria practices, data in the same Table 4 show that the three were no significant differences between Rhizobacterein and Nitrobein on pulp/ stone ratio during both seasons. Concerning the interaction effect between organic fertilizer source, organic fertilizer application methods and biofertilizers $\mathrm{N}$-fixing bacteria treatments on pulp/stone ratio of peaches, data of Table 4 illustrate that fertilization treatments by fish scrap using trench method $\times$ Nitrobein treatment was significantly interactive for pulp/stone of Table 4 illustrate that fertilization treatments by fish scrap using trench method $\times$ Nitrobein treatment was significantly interactive for pulp/stone ratio and gave the highest value in this respect in the both seasons. While, goat manure using trench method $x$ Rhizobacterein and olive pomace using surface method $\times$ Rhizobacterein treatments 
Table 4. Specific effect of organic fertilizer source, fertilizer application method and biofertilizers N-fixing bacteria on fruit and pulp / stone ratio of " Earligrande" peach trees during 2014 and 2015 seasons.

\begin{tabular}{|c|c|c|c|c|}
\hline \multirow{2}{*}{ Treatment } & \multicolumn{2}{|c|}{ Fruit weight (g) } & \multicolumn{2}{|c|}{ Pulp / stone ratio } \\
\hline & $2013 / 2014$ & $2014 / 2015$ & $2013 / 2014$ & $2014 / 2015$ \\
\hline \multicolumn{5}{|c|}{ Specific effect of organic fertilizer source (OF) } \\
\hline Fish scrap & $154.33 \mathrm{a}$ & $136.20 \mathrm{a}$ & $17.64 \mathrm{a}$ & $16.99 \mathrm{a}$ \\
\hline Goat manure & $154.76 \mathrm{a}$ & $130.25 \mathrm{a}$ & $17.03 \mathrm{~b}$ & $16.49 \mathrm{~b}$ \\
\hline Olive pomace & $165.45 \mathrm{a}$ & $133.80 \mathrm{a}$ & $17.15 \mathrm{ab}$ & $16.71 \mathrm{ab}$ \\
\hline Control & $127.46 \mathrm{~b}$ & $140.96 \mathrm{a}$ & $15.99 \mathrm{c}$ & $15.37 \mathrm{c}$ \\
\hline \multicolumn{5}{|c|}{ Specific effect of methods of organic fertilizer application(MA) } \\
\hline Surface application & $153.15 \mathrm{a}$ & $130.15 \mathrm{~b}$ & $17.36 \mathrm{a}$ & $15.91 \mathrm{a}$ \\
\hline Trench application & $147.85 \mathrm{a}$ & $140.45 \mathrm{a}$ & $17.18 \mathrm{a}$ & $17.55 \mathrm{~b}$ \\
\hline \multicolumn{5}{|c|}{ Specific effect of Biofertilizers N-fixing bacteria (BF) } \\
\hline Rhizobacterein & $152.00 \mathrm{a}$ & $136.54 \mathrm{a}$ & $17.02 \mathrm{a}$ & $16.90 \mathrm{a}$ \\
\hline Nitrobein & $149.00 \mathrm{~b}$ & $134.06 \mathrm{~b}$ & $17.52 \mathrm{a}$ & $16.56 \mathrm{a}$ \\
\hline
\end{tabular}

Mean values of treatments were differentiated by using Least Significant Range (Duncan's multiple range test) at $5 \%$ probability

Table 5. The interaction effect between organic fertilizer source, fertilizer application method and biofertilizers $\mathrm{N}$-fixing bacteria on fruit and pulp/stone ratio of "Earligrande" peach trees during 2014 and 2015 seasons.

\begin{tabular}{|c|c|c|c|c|c|c|}
\hline \multicolumn{3}{|c|}{ Treatment } & \multicolumn{2}{|c|}{ Fruit weight (g) } & \multicolumn{2}{|c|}{ Pulp / stone ratio } \\
\hline $\mathbf{O F}$ & MA & BF & $2013 / 2014$ & $2014 / 2015$ & 2013/2014 & $2014 / 2015$ \\
\hline \multirow{4}{*}{ Fish scrap } & \multirow{2}{*}{ Surface } & Rhizobacterein & $154.0 \mathrm{bc}$ & $130.2 \mathrm{ab}$ & $16.42 \mathrm{f}$ & $16.34 d$ \\
\hline & & Nitrobein & $152.4 \mathrm{c}$ & $122.9 \mathrm{ab}$ & $17.45 \mathrm{c}$ & $15.93 \mathrm{def}$ \\
\hline & \multirow{2}{*}{ Trench } & Rhizobacterein & $155.3 \mathrm{abc}$ & 139.7ab & $17.18 \mathrm{cde}$ & $17.17 \mathrm{c}$ \\
\hline & & Nitrobein & $176.7 \mathrm{a}$ & $151.9 \mathrm{a}$ & $19.49 \mathrm{a}$ & $18.51 \mathrm{a}$ \\
\hline \multirow{4}{*}{ Goat manure } & \multirow{2}{*}{ Surface } & Rhizobacterein & $168.0 \mathrm{abc}$ & $127.1 \mathrm{ab}$ & $18.09 \mathrm{~b}$ & $16.18 \mathrm{de}$ \\
\hline & & Nitrobein & $161.5 \mathrm{abc}$ & $117.6 \mathrm{~b}$ & $17.02 \mathrm{de}$ & $15.29 \mathrm{~g}$ \\
\hline & \multirow{2}{*}{ Trench } & Rhizobacterein & $131.6 \mathrm{de}$ & $148.3 \mathrm{ab}$ & $15.74 \mathrm{~h}$ & $18.04 b$ \\
\hline & & Nitrobein & 157.9abc & 127.9ab & $17.26 \mathrm{~cd}$ & $15.48 \mathrm{ef}$ \\
\hline \multirow{4}{*}{ Olive pomace } & \multirow{2}{*}{ Surface } & Rhizobacterein & $175.5 \mathrm{ab}$ & $121.9 \mathrm{ab}$ & $18.18 \mathrm{~b}$ & $14.61 \mathrm{~h}$ \\
\hline & & Nitrobein & $158.8 \mathrm{abc}$ & $139.5 \mathrm{ab}$ & $17.01 \mathrm{de}$ & $17.09 \mathrm{~cd}$ \\
\hline & \multirow{2}{*}{ Trench } & Rhizobacterein & $155.6 \mathrm{abc}$ & $143.0 \mathrm{ab}$ & $16.51 \mathrm{ef}$ & $18.06 \mathrm{~b}$ \\
\hline & & Nitrobein & $150.8 \mathrm{~cd}$ & $130.6 \mathrm{ab}$ & $16.91 \mathrm{def}$ & $17.07 \mathrm{~cd}$ \\
\hline & Control & & $127.46 \mathrm{e}$ & $140.9 \mathrm{ab}$ & $15.99 \mathrm{~g}$ & $15.37 \mathrm{f}$ \\
\hline
\end{tabular}

Mean values of treatments were differentiated by using Least Significant Range (Duncan's multiple range test) at 5\% probability 
had the least values in this regared in both seasons, respectively. Similar results were obtained by Moharam and Zaen El-deen (2011) they revealed that some physical properties of peach fruits (fruit flesh thickness, fruit volume and pulp/stone ratio) were significantly affected by organic fertilizers (olive solid water OSW) types (fresh - compost).

\section{Fruit Size $\left(\mathrm{cm}^{3}\right)$}

Table 6 reveals that in both study seasons, fruit size increased linearly with different organic fertilization. The fish scrap fertilized trees gave the highest values of fruit size in both seasons, followed by goat manure fertilized trees in this concern. On the other hand, the non-organic fertilized trees (control) were the most depressive effect in both seasons. Also data of Table (6) clear that trench application treatment achieved a highest significant increase in fruit size compared to surface application method in both seasons.

Concerning the specific effect of biofertilizers $\mathrm{N}$-fixing bacteria practices, data in the same Table (6) show that the highest fruit size was given by Rhizobacterein. In the meantime, Nitrobein treatment had the least values in this concern in both seasons. Similar results were reported by Fayed (2005a) and Moharam and Zaen El-deen (2011) on peach. Regarding the interaction effect between organic fertilizer source, organic fertilizer application methods and biofertilizers $\mathrm{N}$-fixing bacteria treatments, data of Table (7) show that fertilization treatments by fish scrap $\times$ trench application Rhizobacterein $\times$ treatment were significantly interactive for fruit size during both seasons. While the non-organic fertilized trees gave the least values in this respect in the both seasons.

\section{Fruit firmness $\left(\mathrm{kg.cm}^{-2}\right)$}

Results presented in Table 6 declare that fruit firmness $\left(\mathrm{kg} . \mathrm{cm}^{-2}\right)$ was increased significantly by different organic fertilization sources. The fish scrap treatment produced the highest values of fruit firmness, followed by goat manure treatment. Meanwhile, the least values of fruit firmness were obtained by control treatment in both seasons. These results are in agreement with those reported by ELGioushy and Baiea (2015) who reported that fruit firmness was greatly affected by the studied organic fertilization. As for specific effect of methods of adding organic fertilizer application on fruit firmness $\left(\mathrm{kg} . \mathrm{cm}^{-2}\right)$ of "Earlygrand" peaches during 2014 and 2015 seasons, Table (6) shows that surface application achieved the highest fruit firmness compared to trench application during both seasons.

Concerning the specific effect of biofertilizers $\mathrm{N}$-fixing bacteria practices on fruit firmness $\left(\mathrm{kg} . \mathrm{cm}^{-2}\right)$, data presented in Table 6 show that biofertilizers succeeded in increasing fruit firmness. Rhizobacterein caused a high significant increase in fruit firmness $\left(\mathrm{kg} . \mathrm{cm}^{-2}\right)$. While, Nitrobein gave the least values in this respect during both seasons. Regarding, the interaction effect between organic fertilizer source and biofertilizers $\mathrm{N}$-fixing bacteria under application methods of adding organic treatments on fruit firmness of "Earligrande" peaches during 2014 and 2015 seasons, data of Table (7) show that surface application of fish scrap fertilization with Rhizobacterein biofertilizer was significantly interactive for fruit firmness and gave the highest values in this respect in the both seasons. On the contrary, control treatment had the least values in fruit firmness during both seasons. The other interactions reveal in between effect.

\section{Total Soluble Solids (TSS \%)}

Results in Table 8 notice that the fish scrap treatment recorded the highest values of total soluble solids (TSS), followed by goat manure treatment in both seasons respectively. While, the least values of total soluble solids was obtained by non-organic fertilized trees (control) in both seasons. 
Table 6. Specific effect of organic fertilizer source, fertilizer application method and biofertilizers N-fixing bacteria on fruit size and fruit firmness of "Earligrande" peach trees during 2014 and 2015 seasons.

\begin{tabular}{lcccc}
\hline \multirow{2}{*}{ Treatment } & \multicolumn{2}{c}{ Fruit size $\left(\mathrm{cm}^{3}\right)$} & \multicolumn{2}{c}{ Fruit firmness $\left(\mathrm{kg.cm}^{-2}\right)$} \\
\cline { 2 - 4 } & \multicolumn{2}{c}{ Specific effect of organic fertilizer source $(\mathrm{OF})$} & $2014 / 2015$ \\
\hline Fish scrap & $63.11 \mathrm{a}$ & $71.89 \mathrm{a}$ & $0.41 \mathrm{a}$ & $0.42 \mathrm{a}$ \\
Goat manure & $60.13 \mathrm{ab}$ & $64.53 \mathrm{~b}$ & $\mathbf{0 . 3 5} \mathrm{b}$ & $0.33 \mathrm{~b}$ \\
Olive pomace & $55.50 \mathrm{~b}$ & $60.86 \mathrm{c}$ & $0.26 \mathrm{c}$ & $0.27 \mathrm{c}$ \\
Control & $56.40 \mathrm{~b}$ & $50.47 \mathrm{~d}$ & $0.22 \mathrm{~d}$ & $0.21 \mathrm{~d}$ \\
\hline
\end{tabular}

Specific effect of methods of organic fertilizer application(MA)

\begin{tabular}{lllll}
\hline Surface application & $57.77 \mathrm{~b}$ & $61.29 \mathrm{~b}$ & $0.32 \mathrm{a}$ & $0.31 \mathrm{a}$ \\
Trench application & $59.79 \mathrm{a}$ & $62.59 \mathrm{a}$ & $0.30 \mathrm{~b}$ & $0.30 \mathrm{~b}$
\end{tabular}

\begin{tabular}{|c|c|c|c|c|}
\hline \multicolumn{5}{|c|}{ Specific effect of Biofertilizers N-fixing bacteria (BF) } \\
\hline Rhizobacterein & 59.95 a & $62.95 \mathrm{a}$ & 0.32 a & 0.32 a \\
\hline Nitrobein & $57.61 \mathrm{~b}$ & $60.92 \mathrm{~b}$ & $0.29 \mathrm{~b}$ & $0.29 \mathrm{~b}$ \\
\hline
\end{tabular}

Mean values of treatments were differentiated by using Least Significant Range (Duncan's multiple range test) at $5 \%$ probability

Table 7. Interaction effect between organic fertilizer source, fertilizer application method and biofertilizers $\mathrm{N}$-fixing bacteria on fruit size and fruit firmness of Earligrande peach trees during 2014 and 2015 seasons.

\begin{tabular}{|c|c|c|c|c|c|c|}
\hline \multicolumn{3}{|c|}{ Treatment } & \multicolumn{2}{|c|}{ Fruit size $\left(\mathrm{cm}^{3}\right)$} & \multicolumn{2}{|c|}{ Fruit firmness $\left({\left.\mathrm{kg} . \mathrm{cm}^{-2}\right)}^{-2}\right.$} \\
\hline OF & MA & BF & $2013 / 2014$ & $2014 / 2015$ & $2013 / 2014$ & $2014 / 2015$ \\
\hline \multirow{4}{*}{ Fish scrap } & \multirow{2}{*}{ Surface } & Rhizobacterein & $63.18 \mathrm{~b}$ & $72.72 \mathrm{ab}$ & $0.43 \mathrm{a}$ & $0.45 \mathrm{a}$ \\
\hline & & Nitrobein & $60.26 \mathrm{bc}$ & $68.14 \mathrm{c}$ & $0.41 \mathrm{c}$ & $0.41 \mathrm{c}$ \\
\hline & \multirow{2}{*}{ Trench } & Rhizobacterein & $66.10 \mathrm{a}$ & 74.82 a & $0.42 \mathrm{~b}$ & $0.43 \mathrm{~b}$ \\
\hline & & Nitrobein & $62.90 \mathrm{~b}$ & $71.89 \mathrm{~b}$ & $0.39 \mathrm{~d}$ & $0.38 \mathrm{~d}$ \\
\hline \multirow{4}{*}{ Goat manure } & \multirow{2}{*}{ Surface } & Rhizobacterein & $59.78 \mathrm{~cd}$ & $64.03 \mathrm{de}$ & $0.38 \mathrm{e}$ & $0.36 \mathrm{e}$ \\
\hline & & Nitrobein & 57.31 de & $63.91 \mathrm{de}$ & $0.33 \mathrm{~g}$ & $0.32 \mathrm{~g}$ \\
\hline & \multirow{2}{*}{ Trench } & Rhizobacterein & $61.53 \mathrm{bc}$ & $66.57 \mathrm{~cd}$ & $0.35 \mathrm{f}$ & $0.34 \mathrm{f}$ \\
\hline & & Nitrobein & $61.89 \mathrm{bc}$ & $63.62 \mathrm{e}$ & $0.32 \mathrm{~h}$ & $0.31 \mathrm{~h}$ \\
\hline \multirow{4}{*}{ Olive pomace } & \multirow{2}{*}{ Surface } & Rhizobacterein & $56.32 \mathrm{e}$ & 62.05 ef & $0.30 \mathrm{i}$ & $0.29 \mathrm{i}$ \\
\hline & & Nitrobein & $52.54 \mathrm{f}$ & $58.54 \mathrm{~g}$ & $0.24 \mathrm{k}$ & $0.27 \mathrm{k}$ \\
\hline & \multirow{2}{*}{ Trench } & Rhizobacterein & $59.91 \mathrm{~cd}$ & 62.50 ef & $0.27 \mathbf{j}$ & $0.27 \mathbf{j}$ \\
\hline & & Nitrobein & $53.22 \mathrm{f}$ & $60.36 \mathrm{fg}$ & 0.23 l & 0.241 \\
\hline & Contro & & $56.40 \mathrm{e}$ & 50.47 h & $0.22 \mathrm{~m}$ & $0.21 \mathrm{~m}$ \\
\hline
\end{tabular}

Mean values of treatments were differentiated by using Least Significant Range (Duncan's multiple range test) at 5\% probability 
SINAI Journal of Applied Sciences (ISSN: 2314-6079) Vol. (7) Is. (2), Aug. 2018

Table 8. Specific effect of organic fertilizer source, fertilizer application method and biofertilizers $\mathrm{N}$-fixing bacteria on total soluble solids (TSS), total acidity, TSS/Acid and vitamin C of "Earligrande" peaches during 2014 and 2015 seasons.

\begin{tabular}{|c|c|c|c|c|c|c|}
\hline \multirow[t]{2}{*}{ Treatment } & \multicolumn{2}{|c|}{ Total soluble solids (\%) } & \multicolumn{2}{|c|}{ Total acidity (\%) } & \multicolumn{2}{|c|}{$\begin{array}{c}\text { Vitamin } C \\
\text { (mg /100ml juice) }\end{array}$} \\
\hline & $2013 / 2014$ & $2014 / 2015$ & $2013 / 2014$ & $2014 / 2015$ & $2013 / 2014$ & $2014 / 2015$ \\
\hline \multicolumn{7}{|c|}{ Specific effect of organic fertilizer source (OF) } \\
\hline Fish scrap & 10.39 a & 10.58 a & $0.40 \mathrm{c}$ & $0.40 \mathrm{~b}$ & $7.61 \mathrm{a}$ & $7.79 \mathrm{a}$ \\
\hline Goat manure & $9.72 \mathrm{~b}$ & $9.93 \mathrm{~b}$ & $0.52 \mathrm{~b}$ & $0.54 \mathrm{a}$ & $7.41 \mathrm{~b}$ & $7.57 \mathrm{ab}$ \\
\hline Olive pomace & $9.08 \mathrm{c}$ & $9.27 \mathrm{c}$ & 0.65 a & 0.59 a & $7.23 \mathrm{~d}$ & $7.38 \mathrm{~b}$ \\
\hline Control & $9.00 \mathrm{c}$ & $9.03 \mathrm{~d}$ & $0.58 \mathbf{a b}$ & 0.65 a & $7.35 \mathrm{c}$ & $6.80 \mathrm{c}$ \\
\hline \multicolumn{7}{|c|}{ Specific effect of methods of organic fertilizer application(MA) } \\
\hline Surface application & $9.62 \mathrm{a}$ & $10.23 \mathrm{a}$ & $0.56 \mathrm{a}$ & $0.55 \mathrm{a}$ & $7.42 \mathrm{a}$ & $7.52 \mathrm{a}$ \\
\hline Trench application & $9.47 \mathrm{~b}$ & $9.48 \mathrm{~b}$ & $0.52 \mathrm{~b}$ & $0.54 \mathbf{a}$ & $7.38 \mathrm{~b}$ & $7.24 \mathrm{~b}$ \\
\hline \multicolumn{7}{|c|}{ Specific effect of Biofertilizers N-fixing bacteria(BF) } \\
\hline Rhizobacterein & $9.67 \mathrm{a}$ & $9.85 \mathrm{a}$ & $0.56 \mathrm{a}$ & 0.57 a & $7.44 \mathrm{a}$ & $7.43 \mathrm{a}$ \\
\hline Nitrobein & $9.42 \mathrm{~b}$ & $9.55 \mathrm{~b}$ & $0.53 \mathrm{a}$ & $0.52 \mathrm{a}$ & $7.36 \mathrm{~b}$ & $7.34 \mathrm{~b}$ \\
\hline
\end{tabular}

Mean values of treatments were differentiated by using Least Significant Range (Duncan's multiple range test) at 5\% probability

These results go in line with those reported by El-sayed et al. (2010) and Fawzi et al., (2010) on pomegranate and Moharam and Zaen El-deen (2011) who reported that application of OSW compost gave the highest significant TSS compared to control treatment on peach. From the same Table (8), data showed that the surface application achieved the highest total soluble solids compared to trench application during both seasons. Concerning biofertilizer treatments, it succeeded in increasing total soluble solids in both seasons.

Rhizobacterein caused a high significant increase in total soluble solids. On the contrary, Nitrobein biofertilizer treatment gave the least value in this respect in 2014 and 2015 seasons. Similar results were obtained by Sahain, et al. (2007) who found that TSS $(\%)$ at harvest was improved by two forms EM (a commercial Biostimulant) of effective microorganisms as compared to the control on Anna apple trees.

Regarding, the interaction effect between organic fertilizer source and biofertilizers
$\mathrm{N}$-fixing bacteria under application methods of adding organic treatments, data of Table (9) show that surface application of fish scrap fertilization with Rhizobacterein were significantly interactive for total soluble solids and gave the highest values in this respect in both seasons. While, trench application of olive pomace fertilization with Nitrobein treatment had the least values in this result during both seasons.

\section{Total Acidity "malic acid" (\%)}

Table 8 reveals that in both study seasons, acidity values as malic acid were decreased linearly with adding organic fertilization. The fertilized trees with olive pomace gave the highest values of acidity in both seasons. On the other hand, fertilized trees with fish scrap had the most depressive effect in this respect. These results are in agreement with those reported by EL-Gioushy and Baiea (2015) who reported that acidity was greatly affected by the studied organic fertilization. On the other hand, surface application achieved the highest acidity percentage compared to trench application during first season. 
Table 9. The interaction effect between organic fertilizer source, fertilizer application method and biofertilizers N-fixing bacteria on total soluble solids (TSS), total acidity, TSS/ Acid and vitamin C of "Earligrande" peach trees during 2014 and 2015 seasons.

\begin{tabular}{|c|c|c|c|c|c|c|c|c|}
\hline \multicolumn{3}{|c|}{ Treatment } & \multicolumn{2}{|c|}{ Total soluble solids (\%) } & \multicolumn{2}{|c|}{ Total acidity (\%) } & \multicolumn{2}{|c|}{$\begin{array}{c}\text { Vitamin C } \\
\text { (mg /100ml juice) }\end{array}$} \\
\hline $\mathbf{O F}$ & MA & BF & $2013 / 2014$ & $2014 / 2015$ & 2013/2014 & $2014 / 2015$ & $2013 / 2014$ & $2014 / 2015$ \\
\hline \multirow{4}{*}{$\begin{array}{c}\text { Fish } \\
\text { scrap }\end{array}$} & \multirow{2}{*}{ Surface } & Rhizobacterein & 10.64 a & $10.95 \mathrm{a}$ & 0.44 def & $0.41 \mathrm{de}$ & $7.66 \mathrm{a}$ & $8.08 \mathrm{a}$ \\
\hline & & Nitrobein & $10.30 \mathrm{bc}$ & $10.78 \mathrm{ab}$ & 0.42 ef & 0.42 de & $7.61 \mathrm{~b}$ & $7.90 \mathrm{~b}$ \\
\hline & \multirow{2}{*}{ Trench } & Rhizobacterein & $10.47 \mathrm{ab}$ & $10.47 \mathrm{bc}$ & 0.41 ef & $0.43 \mathrm{de}$ & $7.63 \mathrm{~b}$ & $7.63 \mathrm{e}$ \\
\hline & & Nitrobein & $10.13 \mathrm{~cd}$ & $10.13 \mathrm{~cd}$ & $0.35 \mathrm{f}$ & $0.37 \mathrm{e}$ & $7.56 \mathrm{c}$ & $7.56 \mathrm{f}$ \\
\hline \multirow{4}{*}{$\begin{array}{c}\text { Goat } \\
\text { manure }\end{array}$} & \multirow{2}{*}{ Surface } & Rhizobacterein & $9.97 \mathrm{de}$ & $10.52 \mathrm{~b}$ & 0.58 bc & 0.46 cde & $7.50 \mathrm{~d}$ & $7.81 \mathrm{c}$ \\
\hline & & Nitrobein & $9.61 \mathrm{fg}$ & $9.93 \mathrm{~d}$ & 0.49 cde & $0.65 \mathrm{a}$ & $7.38 \mathrm{f}$ & $7.72 \mathrm{~d}$ \\
\hline & \multirow{2}{*}{ Trench } & Rhizobacterein & 9.81 ef & $9.81 \mathrm{de}$ & $0.54 \mathrm{bcd}$ & 0.45 cde & $7.43 \mathrm{e}$ & $7.43 \mathrm{~h}$ \\
\hline & & Nitrobein & $9.47 \mathrm{gh}$ & 9.47 ef & 0.49 cde & 0.62 ab & $7.33 \mathrm{gh}$ & $7.33 \mathrm{i}$ \\
\hline \multirow{4}{*}{$\begin{array}{c}\text { Olive } \\
\text { pomace }\end{array}$} & \multirow{2}{*}{ Surface } & Rhizobacterein & $9.32 \mathrm{hi}$ & $9.85 \mathrm{~d}$ & 0.70 a & 0.64 a & $7.32 \mathrm{~h}$ & $7.61 \mathrm{e}$ \\
\hline & & Nitrobein & $9.11 \mathrm{ij}$ & $9.32 \mathrm{fg}$ & $0.71 \mathrm{a}$ & $0.64 \mathrm{a}$ & $7.19 \mathrm{j}$ & $7.50 \mathrm{~g}$ \\
\hline & \multirow{2}{*}{ Trench } & Rhizobacterein & $9.18 \mathrm{ij}$ & $9.18 \mathrm{fg}$ & $0.62 \mathrm{ab}$ & 0.52 bcd & $7.28 \mathrm{i}$ & $7.28 \mathrm{j}$ \\
\hline & & Nitrobein & $8.73 \mathrm{k}$ & $8.73 \mathrm{~h}$ & $0.58 \mathrm{bc}$ & 0.56 abc & $7.35 \mathrm{fg}$ & $7.12 \mathrm{k}$ \\
\hline \multicolumn{3}{|c|}{ Control } & 9.00 jk & $9.03 \mathrm{gh}$ & 0.58 bc & $0.65 \mathrm{a}$ & $7.12 \mathrm{k}$ & $6.80 \mathrm{I}$ \\
\hline
\end{tabular}

Mean values of treatments were differentiated by using Least Significant Range (Duncan's multiple range test) at $5 \%$ probability

While, the acidity percentage was not significantly affect by the method of adding organic fertilization in both seasons. But, the acidity values were not significantly affecting by the biofertilizers treatments in both seasons.

Regarding the interaction effect between organic fertilizer source and biofertilizers $\mathrm{N}$-fixing bacteria under application methods of adding organic treatments on acidity value of "Earligrande" peaches during 2014 and 2015 seasons, data of Table (9) indicate that surface application of olive pomace with Rhizobacterein or Nitrobein was significantly interactive for acidity percentage and gave the highest value in this respect in the first season. While, surface application of goat manure or olive pomace fertilization with Rhizobacterein or Nitrobein as well as control treatment recorded the highest value during second season. On the contrary, trench application of fish scrap with Nitrobein treatment had the least value in acidity percentage during both seasons.

\section{Vitamin C Content}

Results presented in Table 8 clear that Vitamin $\mathrm{C}$ was increased significantly by different organic fertilization sources. The fish scrap treatment produced the highest value of vitamin $\mathrm{C}$ content, followed by goat manure treatment in both seasons respectively. Meanwhile, the least values of vitamin $\mathrm{C}$ content were obtained by nonorganic fertilized trees (control) in both seasons. Similar results were obtained by El-Desouky and Abd El-Hamied (2014) they found that using compost as organic fertilization gave the high vitamin $\mathrm{C}$ on pomegranate fruit trees. Also, data showed 
that the surface application achieved the highest vitamin $\mathrm{C}$ compared to trench application during both seasons. Concerning the biofertilizer treatments it succeeded in increasing Vitamin $\mathrm{C}$ in both seasons. Rhizobacterein caused a high significant increase in vitamin $\mathrm{C}$ content while, Nitrobein gave the least values in this respect in 2014 and 2015 seasons. The obtained data are confirmed with those reported by Shrestha et al., (1996) on "Anna" apple trees.

Regarding the interaction effect between organic fertilizer source and biofertilizers $\mathrm{N}$-fixing bacteria under application methods of adding organic treatments, data of Table (9) show that surface application of fish scrap fertilization with Rhizobacterein were significantly interactive for vitamin $\mathrm{C}$ and gave the highest value in this respect in both seasons while, control treatment had the least values in this result during both seasons.

\section{DISCUSSION}

Several studies indicated that the improvement in flowering, resulted by organic fertilization, may be attributed to the stimulation effect of the absorbed nutrients on photosynthesis process which certainly reflected positively on the flowering characteristics (Bhangoo et al., 1988). Also, the slow release nutrients resulted from the biodegradation of manure by soil microorganisms could explain the present results (Cole et al., 1987 and AlKahtani and Ahmed, 2012).

The increase in yield/tree could be due to organic manure effects in increasing the fruit weight during two the studied seasons. In addition, the improving effect of organic manure on fruit yield could be attributed to their vital role in improving tree growth and nutritional status can encourage the cell division and the development of meristematic tissues (Miller et al., 1990) consequently improving the number of inflorescences borne (Al-Wasfy and El-Khawaga, 2008). Nitrobein or Rhizobacterein emphasized the positive action of them, on yield and fruit weight. Besides, the yield as affected by organic and bio- fertilizer could be explained by the ability of N2-fixation, P- solubilising, Indole acetic acid (IAA) and antimicrobial substance production (Cakmakci et al., 2007; Elkoca et al., 2008).

Generally, organic fertilizer increased fruit TSS \% content and total acidity comparing to control treatment of peach trees (Fayed, 2005a, Fayed, 2005b Bahaa, (2007) and Stino et al. 2010). The role of organic fertilizer in improving TSS \% was reported previously by Stino et al., (2010) in peach tree. Also, citrate content of mature peach fruit is correlated negatively with total sugar content. Whereas, increasing in sugar content induce a related reduction in estimated "mitochondrial equipment" which diminishes the potential for citrate synthesis. Furthermore, decreasing percentages of inorganic $\mathrm{N}$ and, at the same time, increasing levels of humic acid resulted in decreasing total acidity of Florida Prince Peach comparing with using the suitable $\mathrm{N}$ completely via inorganic form alone El-Khawaga (2011). In addition to that, increases in total sugars of fruits may result from the increase of chlorophyll content which is combined by an increase in apple leaves photosynthetic capacity and there was a liner relationship between total sugars and total chlorophyll content (El-Motaium, 2007, Stino et al., 2010 El-Khawaga, 2011).

\section{Conclusions}

Finally, from the present study we can recommend that the combination between surface application of organic manure (in form of fish scrap) with biofertilizer in the form (Rhizobacterein) improving "Earligrande" peach productivity and fruit quality under the same condition of our study. 


\section{REFERENCES}

Ahmed, F.F. and M. H. Morsy (2001). Response of "Canino" apricot trees grown in the new reclaimed land to application of some nutrients and ascorbic acid. The fifth Arabian Hort. Conf. Ismailia, Egypt, pp. 27-34.

Al-Kahtani S.H. and M.A. Ahmed (2012). Effect of different mixtures of organic fertilizers on vegetative growth, flowering, fruiting and leaf mineral content of Picual olive trees. AmericanEurasian J. Agric. \& Environ. Sci., 12 (8): 1105-1112.

Al-Wasfy M.M. and A.S. El-Khawaga (2008). Effect of organic fertilization on growth, yield and fruit quality of Zaghloul date palm grown in sandy soil. Assiut J. of Agric. Sci., 39 (1) (121-133).

AOAC. (1990). Official Methods of Analysis. $15^{\text {th }}$ Ed., Association of official agriculture chemists Washington D.C., USA.

Bahaa, M.S. (2007). Organic and biofertilization of peach trees. M.Sc. Thesis, Fac. Agric, Cairo Univ., Egypt, pp: 101.

Bekele, D.A. and G.S. Geleta (2015). Iodometric Determination of the Ascorbic Acid (Vitamin C) content of some Fruits consumed in Jimma Town Community in Ethiopia. Res. J. Chem. Sci., 5 (1): 60-63.

Bhangoo, M.S., K.S. Day, V.R. Sualanagunta and V.E. Petrucet (1988). Application of poultry manure influence on Thompson seedless grape production and soil properties. Hort. Sci., 23: 1010-1012.

Cakmakci, R.; M. Erat; U. Erdogan and M.F. Donmez (2007). The influence of plant growth- promoting rhizobacteria on growth and enzyme activities in Wheat and spinach plants. J. Plant Nutr. and Soil Sci., 170: 288-295.
Cole, C.V.; J. Williams, M. Shaffer and J. Hanson (1987). Nutrients and organic matters as components of agricultural production system models. SSSA Spec. Madison, WI., 19: 147-166.

Duncan, B.D. (1955). Multiple Range and Multiple F-tests. Biometrics, 11: 1- 42.

EI-Deeb M.D. 2003. The use some organic and bio-fertilizers for Manzanillo olive trees fertilization. B. Fruiting and fruit quality. Agricultural research Journal, Suez Canal University. 2 (1): 2003: 4352.

El-Desouky M.I. and S. Abd El-Hamied A. (2014). Improving growth and productivity of pomegranate fruit trees planted on sandy dunes slopes at Baloza District (N. Sinai) using different methods of drip irrigation, organic fertilization, and soil mulching. OSR Journal of Agriculture and Veterinary Science (IOSR-JAVS). Volume 7, Issue the 12 Ver. II (Dec. 2014), PP 86-97.

El-Gioushy, S.F. and M.H.M. Baiea (2015). Partial substitution of chemical fertilization of Canino apricot by bio and organic fertilization. Middle East Journal of Applied Sciences. 05 ( 04): 823-832.

El-Khawaga, A.S. (2011). Partial replacement of mineral $\mathrm{n}$ fertilizers by using humic acid and spirulina platensis algae biofertilizer in florida prince peach orchards. Middle East J. Appl. Sci., 1 (1): $5-10$

Elkoca, E; F. Kantar and F. Sahin (2008). Influence of nitrogen fixing \& phosphorus solubilizing bacteria on the nodulation, plant growth, and yield of Chickpea. J. of P. Nutr.31: 157-171 .

El-Motaium, R.A. (2007). Effect of composted municipal solid wastes on growth, nutritional status and fruit quality of apple trees grown in sandy soil: organic farming. Bull. Fac. Agric., Cairo Univ., 58: 198-206. 
El-Sayed E.K.A.; S.S. Mervate and A.Z. Wafaa (2010). Effect of some organic and mineral fertilizer applications on growth and productivity of pomegranate trees. Alex. Sci. Exchange Journal, 31 (3): $296-304$.

El-Shenawy, I.E. and T.A. Fayed (2005). Evaluation of the conventional to organic and bio-fertilizers on "Crimson seedless" Grapevines in comparison with chemical fertilizers. B-Yield and fruit quality. Egyptian J. Appl. Sci., 20 (1): 212-225.

Fawzi M.I.; F.M. Shahin; A. Elham Daood and E.A. Kandil (2010). Effect of organic and biofertilizers and magnesium sulphate on growth yield, chemical composition and fruit quality of "Le-Conte" pear trees. Nature and Science, 2010; 8(12). 273-280.

Fayed, T.A. (2005a). Response of desert red peach trees to organic and some biofertilizers in comparison with the chemical fertilizers. B- yield, fruit quality, and bud state. E. J. of Appl. Sci. 20 (1): 144-158.

Fayed, T.A. (2005b). Effect of some organic manures and bio-fertilizers on Anna apple trees. B- Yield and fruit characteristics. Egyptian journal of Appl. Sci., 20(1) 176-191.

Ferguson, L.; G.S. Sibbett and G.C. Martin (1994). Olive production manual. University of California, Division of Agriculture and Natural Recourses, Oakland, CA. Publication 3353. $160 \mathrm{pp}$.

Hoda A. Khalil (2012). The potential of biofertilizers to improve vegetative growth, nutritional status, yield and fruit quality of Flame Seedless grapevines. American-Eurasian J. Agric. \& Environ. Sci., 12 (9): 1122-1127.

Kassem, H.A. and A.M. El-Seginy (2002). Response of Florida Prince peach trees to soil and foliar application of potassium. J. advanced Agric. Res., 7 (1) 103-115.

Mansour, A.E.M. (1998). Response of Anna apple to some bio-fertilizers. Egyptian Journal of Horticulture 26(1):718.

Melo, G.W.B; P. Sete; V. Ambrosini; R. Freitas; A. Basso and G. Brunetto (2016). Nutritional status, yield and composition of peach fruit subjected to the application of organic compost. Maringá, v. 38(1): 103-109, Jan.-Mar.

Miller, E.W.; R.L. Donahua and J.U. Miller (1990). Soil "an introduction to soils and plant growth". Brentice Hall.

Ministry of Agriculture, A.R.E. (2017). Economic, Agriculture, Department of Agriculture Economic and Statistics.

Moharam F.A. and E.M.A. Zaen El-Deen (2011). Effect of partial substitution of mineral fertilizers with organic fertilizers on peach production under supplemental irrigation in North Sinai. Research J. Agric. and Biolo. Sci, 7(6): 434-442, 2011.

Narayan A.H.; P.N. Singh; S.K. Singh and A.A. Visen (2016). Effect of organic manures on the flowering, fruiting and yield of peach (Prunus persica Batsch) cv. Florida Prince. Indian J., 17 (1):78-83.

Rivera-Cruz, M.; A. Trujillo; G. Córdova; J. Kohler; F. Caravaca and A. Roldán (2008). Poultry manure and banana waste are effective bio-fertilizer carriers for promoting plant growth and soil sustainability in banana crops. Soil Biology and Biochemistry, 40, 30923095. ttp://dx.doi.org/10.1016/j.soilbio. 2008.09.003.

Russell, D.F. (1986). MSTATC Director, crop and soil sciences Department, Michigan State University, Computer Program Package Version 2.10. 
Sahain M.F.; Z. Elham Abd El Motty; H.M. El- Shiekh and F. Laila Hagagg (2007). Effect of some biostimulant on growth and fruiting of Anna apple trees in newly reclaimed areas. Research J. of Agric. and Biolo.. Sci., 3(5): 422-429.

\section{Shrestha, Y.H.; T. Ishii; T. Matsumoto} and K. Kadoya (1996). Effect of vesicular- arbuscular mycorrhizal fungi on Anna apple tree growth and water stress tolerance and fruit development and quality. J. of Japanese Soc.of Hortic. Sci., 64 (4):801-807. (Hort.Abst., 665377)
Stino, R.G., T.A. Fayed, M.M. Ali and S.A. Alaa (2010). Enhancing fruit quality of Florida Prince peaches by some foliar treatments. Journal of Hort. sci. and orname. plants, 2(1): 38-45.

Vogtman, H. and K. Fricke (1989). Nutrient value and utilization of biogenic composts in plant production. Agric. Ecosyst. Environ, 27: 471-475.

Westwood, M.N. and A.N. Roberts (1970). The relationship between trunk cross-sectional area and weight of apple trees. J. Ame. Soc. Hort. Sci. 1970, 95: 28-30.

\section{الملخص العربى}

استخدام بعض الأسمدة العضوية والحيوية لتسميد أشجار الخوخ إيرلى جراند تحت ظروف شمال سيناء

\section{ب. محصول الثمار وجودة الثمار}

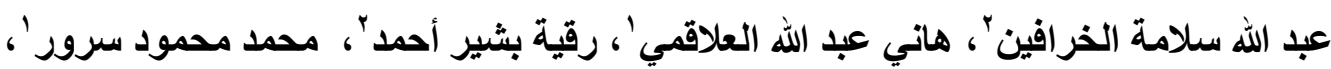

ومحمد دياب الديب'

$$
\text { ا ـ قسم الإنتاج النباتي ـ كلبة العلوم الزر اعية البيئية - جامعة العريش - مصر. }
$$

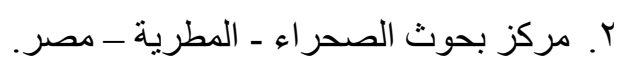

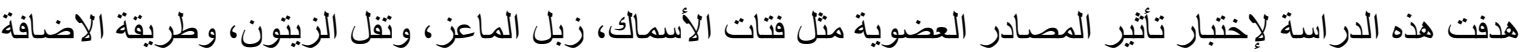

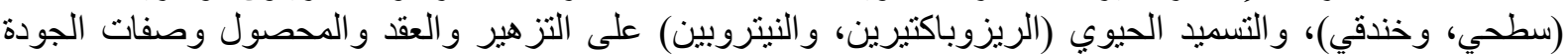

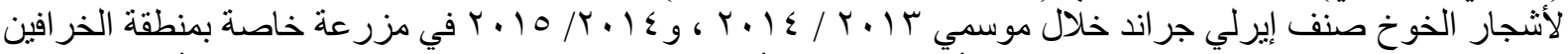

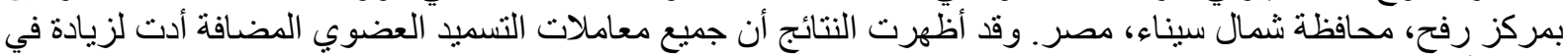

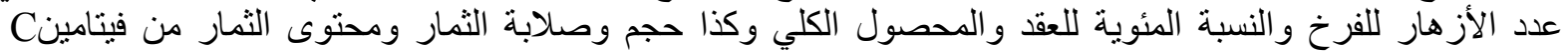

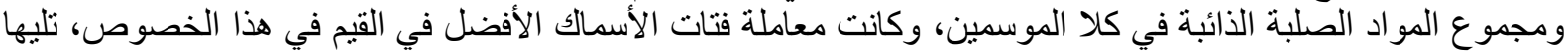

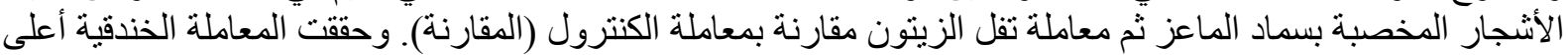

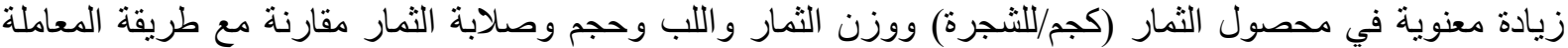

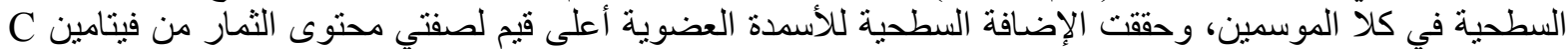

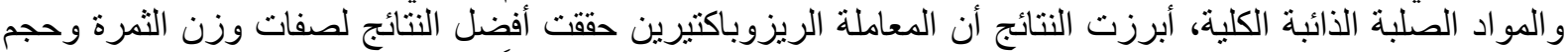

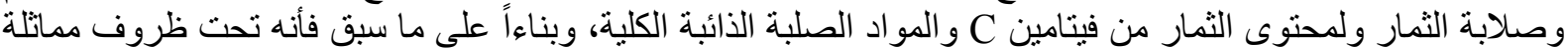

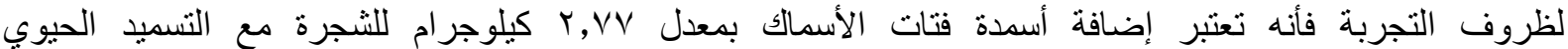

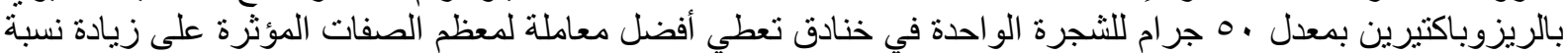

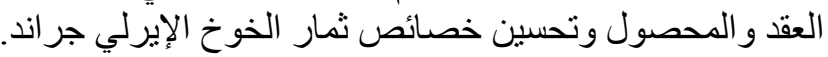
الكلمات الاسترشادية: الخوخ (إيرلى جراند)، فتات السمك، سماد الماعز، الإضافة الخندقية، التسميد الحيوى. 